\title{
Developing a digital platform for knowledge disclosure of land subsidence
}

\author{
Hiddo Velsink ${ }^{1}$, Ursula Backhausen ${ }^{1}$, and Geert J. Roovers ${ }^{2}$ \\ ${ }^{1}$ Research Group Digital Smart Services, Utrecht University of Applied Sciences, \\ Utrecht, P.O. Box 182, 3500 AD, the Netherlands \\ ${ }^{2}$ Research Group Subsurface Issues, Saxion University of Applied Sciences, \\ Enschede, P.O. Box 70000, 7500 KB, the Netherlands \\ Correspondence: Hiddo Velsink (hiddo.velsink@hu.nl) \\ Published: 7 May 2020
}

\begin{abstract}
Land subsidence in areas with weak soils affects a large part of the Netherlands and causes many problems. To solve them diverse and specialized knowledge of possible measures to prevent, mitigate or reverse land subsidence is needed. This knowledge is fragmented over many agencies, companies and individuals. Here we show how data and knowledge are related and we stress the importance of implicit knowledge for knowledge transfer on land subsidence. It is demonstrated that land subsidence in the Netherlands is a "wicked problem". This makes its solution cumbersome. However, we show that self-learning digital environments can help considerably in knowledge acquisition, storage and retrieval. We give an inventory of research questions that have still to be answered to make an digital environment really effective for a wicked problem like land subsidence.
\end{abstract}

\section{Introduction}

In the Netherlands, significant land subsidence takes place in areas with "weak soils" (peat and clay soils) (Fig. 1). The need to tackle the problem is big.

Several public authorities in the Netherlands on state, provincial and municipality level have taken initiatives to improve knowledge and knowledge dissemination on land subsidence, for example by: the establishment of the Platform Slappe Bodem (weak soils platform), a collaboration of twenty municipalities and six water boards (in 2015); the launch of the National Knowledge Program on Land Subsidence by several public authorities (in 2016), which started many so-called "knowledge expeditions" in 2018 and 2019; the inclusion of land subsidence in the Inter-administrative Program (in February 2018) and in the Delta Program on Spatial Adaptation (in September 2018) by the national government; and, finally, the deal on the Green Heart Region between the government and several public authorities (in November 2018). These initiatives show that dealing with land subsidence is socially and administratively urgent for the Netherlands.
Knowledge and experience with regard to land subsidence is widely available in the Netherlands, at public authorities, knowledge institutions and engineering firms. They are available in the form of reports, digital tools and the knowledge and experience of experts. However, recording and dissemination are not performed in a structured manner (Twynstra Gudde, 2018; Witteveen+Bos, 2016). Existing knowledge and experience is often fragmentarily available, which makes them difficult to disclose to all potentially interested parties. This makes it difficult to apply adequate solutions for land subsidence problems (Twynstra Gudde, 2018). This situation is experienced in the Netherlands as problematic for professional practice. In addition, new knowledge is developed rapidly and new experiences are gained continuously. This problem gave rise to research on how this problematic disclosure of knowledge on land subsidence in the Netherlands could be tackled. Furthermore, public authorities asked how a digital platform or tool could facilitate such knowledge disclosure.

This article describes the first results of this research and defines resulting new research questions. The research was carried out in the period 2017-2018 based on three com- 


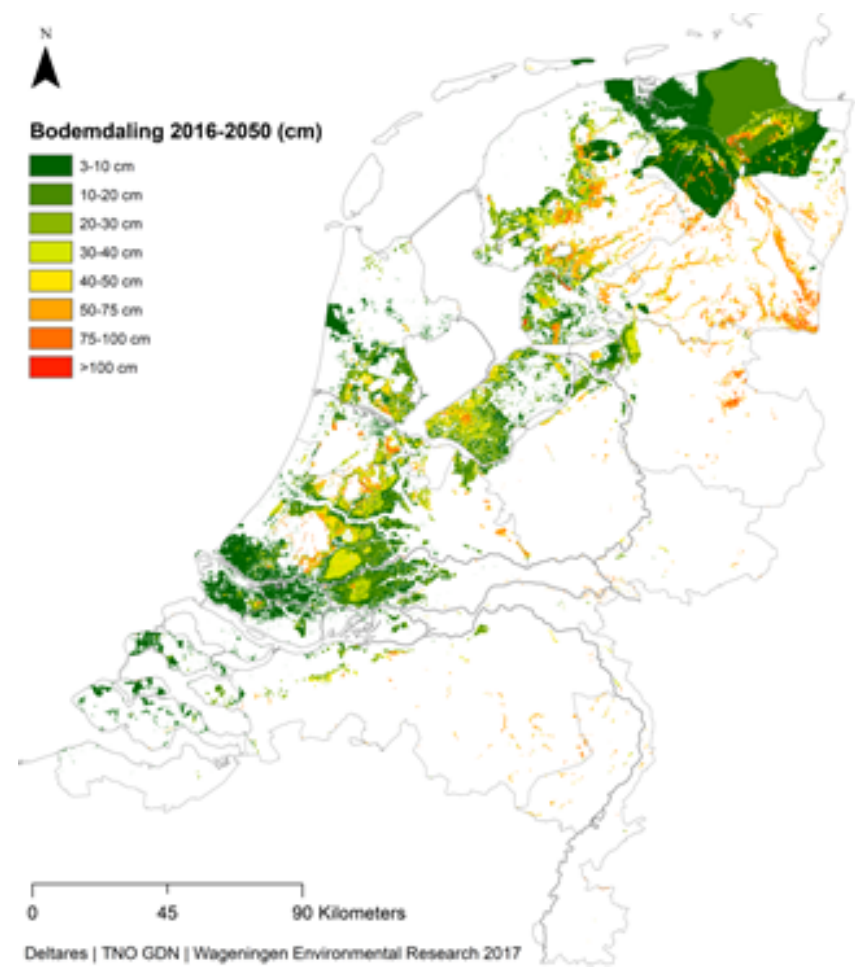

Figure 1. Estimation of land subsidence in the Netherlands 20162050 (Klimaateffectatlas, 2017).

ponents: (1) extensive desk research on theoretical international literature and practical publications in the Netherlands, (2) three bachelor student projects, and (3) five working sessions with professionals in the field of land subsidence in the Netherlands.

This article first describes the theoretical basis of knowledge and knowledge disclosure on land subsidence. Subsequently it describes the situation in professional practice in the Netherlands and analyses this situation. Finally conclusions are drawn and suggestions for further research identified.

\section{Knowledge disclosure on land subsidence}

\subsection{Land subsidence}

Land subsidence in peat and clay soils occurs in six of the twelve provinces of the Netherlands. The expected subsidence until 2050 varies from a few centimeters to two meters. This subsidence is the result of centuries of interventions in the soil and water system (Van den Born et al., 2016; Erkens et al., 2015; Seijger and Verheijen, 2015). Land subsidence due to natural causes (tectonic earth movements, sedimentation and compression) is often limited to a few millimeters per year. Land subsidence due to human causes (compression, drainage and oxidation) can amount to decimeters per year (Erkens et al., 2015).
Land subsidence has five possible consequences (Erkens et al., 2015; Pieterse et al., 2015): (1) increased flood risks, (2) damage to buildings, foundations and infrastructure, (3) pressure on land use, including the possible disappearance of the peat meadow landscape, (4) increased $\mathrm{CO}_{2}$ emissions, influencing climate change, and (5) increasingly complex water management.

The Netherlands Environmental Assessment Agency calculated that land subsidence will cost society 22 billion euros until 2050 (Van den Born et al., 2016).

Effective governance of land subsidence in the Netherlands is difficult (van Buuren et al., 2017; Erkens et al., 2015; van Hardeveld et al., 2014; Seijger and Verheijen, 2015; Witteveen+Bos, 2016): (1) Subsidence is a creeping process, and therefore difficult to see; (2) The soil structure is heterogeneous and uncertain. As a result, there is uncertainty about the effectiveness of measures; (3) Local spatial differences require customization and differentiation; (4) The costs and benefits are skewed: government agencies pay for a significant part of the costs, while citizens and entrepreneurs enjoy the benefits. (5) The responsibilities are fragmented and the issues transcend administrative and organizational boundaries. The state, provinces, municipalities, water boards and utility companies have to work together, often with different perspectives on the issue. (6) Residents and entrepreneurs are responsible for tackling problems for their homes and land. They have, however, a limited awareness of the consequences of land subsidence and their responsibility therein. (7) The role of land subsidence in local assessment processes: in general, soil conditions are considered to be a technical problem that requires a technical solution.

Land subsidence can, therefore, be seen as a "wicked problem" (Erkens et al., 2015; Rittel and Webber, 1973). A problem is wicked, if (1) it is intertwined with various related problems and knowledge fields, if (2) many different stakeholders with their own interests are involved, with different - often conflicting - perceptions and insights, and if (3) the problem has major consequences. This means that a detailed elaboration and application of measures is not sufficient. Dealing with land subsidence requires a learning, interactive approach, aimed at a coherent action perspective in which the complexity of land subsidence is given a place and parties work together to be effective (Grin et al., 2010; Levin et al., 2012; Metze and Turnhout, 2015).

\subsection{Data, information and knowledge}

To disclose knowledge requires a distinction between data, information and knowledge (Baumard, 1999; Nonaka and Takeuchi, 1995; Weggeman, 2000). Data is data that has not yet been given meaning. Information is data that has been given meaning and that is recorded in documents, information systems and/or networks. This is called explicit knowledge. It remains in an organization when all people are gone. Implicit knowledge (also known as experiential knowledge 
or tacit knowledge) is knowledge that a person has acquired through the combination of explicit knowledge and experience. This knowledge is not explicitly available in a document. Implicit knowledge is no longer present in an organization when people have left. Weggeman (2000) uses the relation $K=f(I, E, S, A)$. Knowledge $(K)$ is a function of Information $(I)$, Experience $(E)$, Skills $(S)$ and Attitude $(A)$. Information therefore only becomes knowledge when it is enriched with experience, skills and attitude. Implicit knowledge plays a (still) large(r) role within a "wicked problem" context; experience and learning are even more important. This means that unlocking knowledge on land subsidence and a digital environment that supports this - must be about unlocking explicit knowledge as well as unlocking implicit knowledge.

\subsection{Disclosing explicit knowledge}

Finding, disclosing and using explicit knowledge on land subsidence, using a digital environment, has to take account of four points: availability, uncertainty, accessibility and reliability of knowledge (Cash et al., 2003; Koppenjan and Klijn, 2004; Lavis et al., 2003). These four points are explained here: (1) Availability: is the knowledge you need already present? (2) Uncertainties: which uncertainties are there? Not only with regard to knowledge, but also with regard to underlying assumptions/different calculation methods/models. (3) Accessibility: is there any knowledge at all about a specific theme? Is it accessible/available? And if so, how much energy (transaction costs) must be invested in acquiring this knowledge? (4) Usefulness of knowledge: knowledge must be relevant, credible and legitimate for this purpose.

\subsection{Disclosing implicit knowledge}

Implicit knowledge is crucial for interpreting a wicked problem and finding an appropriate solution (Baumard, 1999; de Bruijn, 2008; Koppenjan and Klijn, 2004; Nonaka and Takeuchi, 1995; Weggeman, 2000). Implicit knowledge requires personal mechanisms and interaction to be shared (Carrillo et al., 2006). These mechanisms often translate into consultation moments, workshops, training courses, mentoring, etc. (Argote and Ingram, 2000; Goh, 2002). Experimental instruments such as semi-structured interviews, stories and films are used to record implicit knowledge.

\subsection{Use of digital environments}

Digital environments can be used to improve knowledge transfer (Twynstra Gudde, 2018). Digital environments are (mostly) concerned with explicit knowledge, which is preserved, stored and shared via databases, intranet and digital platforms. In recent decades there has been a strong development in these facilities (Schindler, 2002). As they develop, it becomes increasingly easier, faster, more effective and more efficient to communicate and share knowledge, both inside and between organizations (Schindler, 2002). In addition, more people have easy access to knowledge.

To include implicit knowledge in a digital environment, the experimental instruments, mentioned in the previous section, are suitable, provided that the recordings are made searchable.

In recent decades, there has been a rise in self-learning digital systems (machine learning). These systems enable efficient searching and management of large - and everincreasing - amounts of knowledge, fragmented across many sources (Diakopoulos, 2014; Domingos, 2015; Hosmer et al., 2013; Quinlan, 2014; Singh et al., 2019; Stanley, 2017; Witten et al., 2016).

Self-learning systems collect very many results and recognize patterns in them, whose parameters are used to make predictions for new situations. Using self-learing systems, intelligence can be built into the digital environment (Domingos, 2015; Käfer and Harth, 2018; Stanley, 2017; Witten et al., 2016): (1) Intelligence to find the right terms and concepts in reports and texts and store them via "linked data" (data stored on the internet in a standardized way and provided with a unique URL). (2) Intelligence to perform calculations and monitoring, for example of expected land subsidence.

\section{Analysis}

Based on the previous sections, one can distinguish four essential issues concerning disclosure of knowledge on land subsidence:

1. Governance of land subsidence is difficult, involving different stakeholders, issues and levels, in which stakeholders have different perceptions. There is no such thing as "one" or "best" solution.

2. Land subsidence is a wicked problem, and thus asks for a learning approach.

3. Knowledge consists of data, information (explicit knowledge) and implicit knowledge. All these aspects have to be addressed. Especially implicit knowledge asks for face-to-face interaction to enable disclosure.

4. Digital environments, capable of self-learning, are crucial to support an effective disclosure of knowledge, but always in coherence with face-to-face learning.

These four issues have to be tackled before one can arrive at a successful digital platform for knowledge disclosure of land subsidence. This has several consequences. A supporting digital environment must focus on unlocking both explicit knowledge and implicit knowledge. To this end, the digital environment must take account of the availability, 
uncertainties, accessibility and reliability of explicit knowledge. The digital environment must function within a learning network of parties that support each other and must work together to cope with land subsidence. From the perspective of knowledge impact between organizations, it can be concluded that knowledge arises in and works through networks of organizations and around practical cases, where everyone uses and produces knowledge. This means that it is not only important to have support from a digital network, when searching for and finding the right knowledge, but also to easily record available knowledge in the digital network. In addition, knowledge transfer depends on the presence of a knowledge infrastructure (ICT), the time pressure, the organizational culture, the working method of the management and the way in which the parties involved work together. The process of knowledge transfer depends on the personal motives and the mutual relationship between the knowledge transferors. Furthermore, the uptake and use of knowledge in an organization depends on the incentive to acquire new knowledge, the absorption capacity of the organization, the organizational structure and the availability of knowledge reservoirs. Finally, a digital environment that supports the dissemination of knowledge for land subsidence must itself also be learning, so that it can increasingly and effectively respond to the user's question and interpretation of this question in the context of the wicked land subsidence problem. In addition, efficient searching for, and management of, the large - and ever increasing - amount of knowledge, fragmented across many sources, also requires a smart and selflearning digital environment. Such a system uses insights in the field of machine learning and self-learning algorithms. These requirements for access to knowledge and the use of a digital environment, in particular with regard to the role in the learning network and the interpretation of the question in the context of a wicked problem, mean that the digital environment goes beyond what is called a knowledge system or expert system in current literature.

\section{Conclusions}

Question: How can the problematic disclosure of knowledge on land subsidence in the Netherlands be tackled, and how can a digital platform facilitate such knowledge disclosure?

We conclude that: (1) the current knowledge needs of professionals and the current knowledge disclosure process are not clear, (2) there is not yet an adequate digital environment that supports this knowledge disclosure, (3) such a digital environment must support a network of parties, aimed both at unlocking and recording knowledge, (4) such a digital environment must support the search process for implicit and explicit knowledge, and (5) such a supportive digital environment must be self-learning. This leads to the following research question and underlying sub questions:
1. What is the knowledge requirement of professionals regarding land subsidence?

2. How does the current knowledge dissemination process take place (seeking and recording knowledge) regarding land subsidence within the relevant network of parties?

3. How can this knowledge disclosure process be improved?

4. How can a digital environment strengthen this knowledge disclosure process?

5. How can such a digital environment look like?

We will address these questions in future research.

Data availability. No observational data were acquired in this research. All other data can be accessed via the references.

Author contributions. The research was designed, the necessary data collected and conclusions drawn by all three authors in collaboration. GJR wrote the first set-up of the article, UB and HV made comments and suggested improvements. Finally HV rearranged and translated the article, sharpened statements and conclusions and made the article comply with the requirements of TISOLS.

Competing interests. The authors declare that they have no conflict of interest.

Special issue statement. This article is part of the special issue "TISOLS: the Tenth International Symposium On Land Subsidence - living with subsidence". It is a result of the Tenth International Symposium on Land Subsidence, Delft, the Netherlands, 17-21 May 2021.

\section{References}

Argote, L. and Ingram, P.: Knowledge Transfer: A Basis for Competitive Advantage in Firms, Organ. Behav. Hum. Dec., 82, 150$169,2000$.

Baumard, P.: Tacit knowledge in organizations, Sage Publications Ltd, London, https://doi.org/10.4135/9781446217375, 1999.

Carrillo, P. M., Robinson, H. S., Anumba, C. J., and Bouchlaghem, N. M.: A knowledge transfer framework: The PFI context, Constr. Manag. Econ., 24, 1045-1056, 2006.

Cash, D. W., Clark, W. C., Alcock, F., Dickson, N. M., Eckley, N., Guston, D. H., Jäger, J., and Mitchell, R. B.: Knowledge systems for sustainable development, P. Natl. Acad. Sci. USA, 100, 80868091, 2003.

de Bruijn, H.: Managers en professionals. Over management als probleem en als oplossing, Boom uitgevers Amsterdam, 2008.

Diakopoulos, N.: Algorithmic accountability reporting: On the investigation of black boxes, Tow Center for Digital Journalism, Columbia University, 2014. 
Domingos, P.: The master algorithm, Basic Books, New York, 2015.

Erkens, G., Bucx, T., Dam, R., De Lange, G., and Lambert, J.: Sinking coastal cities, Proceedings of the International Association of Hydrological Sciences, 372, 189, 2015.

Goh, S. C.: Managing effective knowledge transfer: An integrative framework and some practice implications, J. Knowl. Manag., 6, 23-30, 2002.

Grin, J., Rotmans, J., and Schot, J.: Transitions to sustainable development: New directions in the study of long term transformative change, Routledge, New York/London, 2010.

Hosmer, D. W., Lemeshow, S., and Sturdivant, R. X.: Applied Logistic Regression, 3rd Edn., Wiley, New Jersey, 2013.

Käfer, T. and Harth, A.: Specifying, monitoring, and executing workflows in linked data environments, in: The Semantic Web ISWC 2018, ISWC 2018. Lecture Notes in Computer Science, Vol. 11136, edited by: Vrandečić, D., Bontcheva, K., SuárezFigueroa, M. C., Presutti, V., Celino, I., Sabou, M., Kaffee, L.-A., and Simperl, E., 424-440, Springer, Cham., 2018.

Klimaateffectatlas: Deltares, TNO GDN, Wageningen Environmental Research, 2017

Koppenjan, J. and Klijn, E. H.: Managing Uncertainties in Networks, Taylor and Francis Ltd., New York/London, 2004.

Lavis, J. N., Robertson, D., Woodside, J. M., McLeod, C. B., and Abelson, J.: How can research organizations more effectively transfer research knowledge to decision makers?, Milbank Q., 81-82, 221-248, 2003.

Levin, K., Cashore, B., Bernstein, S., and Auld, G.: Overcoming the tragedy of super wicked problems: Constraining our future selves to ameliorate global climate change, Policy Sci., 45, 123152,2012

Metze, T. and Turnhout, E.: Politiek, participatie en experts in de besluitvorming over super wicked problems, Bestuurskunde, 23, 3-11, 2015.

Nonaka, I. and Takeuchi, H.: The Knowledge-Creating Company, Oxford University Press Inc, Oxford, 1995.

Pieterse, N., Broek, L. van den, Pols, L., and Huitzing, H.: Het Groene Hart in Beeld, Planbureau voor de Leefomgeving, Den Haag, available at: https://www.pbl.nl/sites/default/ files/downloads/PBL2015_Het_Groene_Hart_2e_druk_1351_ juli2015.pdf (last access: 6 May 2020), 2015.

Quinlan, J. R.: C4.5: programs for machine learning, Elsevier, Amsterdam, 2014.

Rittel, H. W. J. and Webber, M. M.: Dilemmas in a general theory of planning, Policy Sci., 4, 155-169, 1973.
Schindler, M.: Wissensmanagement in der Projektabwicklung, Lohmar, Köln, 2002.

Seijger, C. and Verheijen, E.: Governance handelingsperspectieven voor bodemdaling in Gouda, Deltares, Delft, 2015.

Singh, V., Bano, S., Yadav, A. K., and Ahmad, S.: Feasibility of Artificial Neural Network in Civil Engineering, International Journal of Trend in Scientific Research and Development, 3, 724728, 2019.

Stanley, J.: Pitfalls of Artificial Intelligence Decisionmaking Highlighted In Idaho ACLU Case, available at: https://www.aclu.org/blog/privacy-technology/pitfalls-artificialintelligence-decisionmaking-highlighted-idaho-aclu-case (last access: 6 May 2020), 2017.

Twynstra Gudde: Context - en probleemanalyse voor kennisdoorwerking. Uitvoeringsprogramma Bodem en Ondergrond, Twynstra Gudde, Amersfoort, the Netherlands, 2018.

van Buuren, A., Bil, J. A., and Roovers, G. J.: Styles of public asset management in Dutch regional water management, in: 5th International Symposium on Life-Cycle Engineering, IALCCE 2016, edited by: Bakker, J., Frangopol, D. M., and van Breugel, K., 567-574, Taylor and Francis Group, Delft, the Netherlands, 2017.

Van den Born, G. J., Kragt, F., Henkens, D., Rijken, B., Van Bemmel, B., and Van der Sluis, S.: Dalende bodems, stijgende kosten, PBL report 1064, Planbureau voor de Leefomgeving, Den Haag, the Netherlands, 2016.

van Hardeveld, H., van der Lee, M., Strijker, J., van Bokhoven, A., and de Jong, H.: Toekomstverkenning Bodemdaling; eindrapport fase 1, Hoogheemraadschap De Stichtse Rijnlanden, Provincie Utrecht, Provincie Zuid-Holland, available at: https://www.veenweiden.nl/wp-content/uploads/2015/07/ Eindrapport-Toekomstverkenning-bodemdaling-fase-1.pdf (last access: 6 May 2020), 2014.

Weggeman, M. C. D. P.: Kennismanagement: de praktijk, Scriptum Management, Schiedam, the Netherlands, 2000.

Witten, I. H., Frank, E., Hall, M. A., and Pal, C. J.: Data Mining: Practical Machine Learning Tools and Techniques, Elsevier Inc., Amsterdam, the Netherlands, 2016.

Witteveen+Bos: Kennisagenda Slappe Bodem. Inventarisatie en invulling kennisagenda Slappe Bodem, Witteveen+Bos, Deventer, the Netherlands, 2016. 